\title{
Actualizing Communities of Practice (COPs) and Situated Learning for A Sustainable Eco-Village
}

\author{
Maria Victoria Pineda
}

\begin{abstract}
An eco-village as defined by Robert Gilman is a "human-scale, full-featured settlement where you feel you know the others, and human activities are integrated with natural, biological systems." Roland Mayerl argued that this maybe ideal, but there are huge challenges. He claims the challenges are at different levels-there is the physical layer that constitutes food production, animals, water and wastewater treatment. Other layers will be the built environment, the economic system and the governance in the village.

This paper argues that one of the challenging layers is the human layer that was excluded in the modeling of many eco-village works. While there are many good models of an eco-village, sustainability will primarily be laid on the shoulders of the members of the community or the village for that matter. Sustainability should be espoused by the members of the eco-village. But how can sustainability be attained? What sustainability approach or strategy can be employed?

"Communities of practice (COP) are formed by people who engage in a process of collective learning in a shared domain of human endeavor." (Wenger, 2004) COPs are concepts commonly applied in organizations and virtual communities. Using this approach together with periphery participation and situated learning, this paper presents a human-based model of a sustainable eco-village and some useful examples.

The paper also argues that an eco-village necessitates the support of technology in enhancing and preserving the shared practices. Hence, use of social media deployed in the web is one of the recommended ways that also permit collective action among members of the eco-village.
\end{abstract}

Keywords: communities of practice, sustainable eco-village, situated learning, periphery learning

\section{The Eco-Village Principles}

The seminal work of Robert Gilman (1991) expounds on the eco-village as "human-scale, fullfeatured settlement in which human activities are harmlessly integrated into the natural world". Gilman also stressed to continuously and healthily "support human development”. By definition, eco-village prescribes a modest village size where members of the community have the opportunity to know and be familiar with each other. The village should be in healthy conduit with other forms of living beings, following green principles and cooperation philosophy (EarthTalk, 2008). Green principles adhere to ecologically sustainable environment while having opportunities of normal living functions such as residential, business, social, leisure and manufacturing activities. Green principles further advocate a strong balance between ecological sustainability and urban way of living. Gilman's eco-village principles proposed a community of less than five hundred members (Gilman, 1991) while Earth Talk recommended up to one hundred fifty members (EarthTalk, 2008).

While Mayerl (2010) noted that the traditional villages were patriarchal and ruled by mistrust within the villages, modern and present residential developers tend to anchor on the idea of secure, 
balanced, harmonious and spacious villages. But generally, densely populated villages in resonance with the environment is not anymore observable both in the rural and urban areas especially in the case of a developing country like the Philippines.

\section{Human Factor, A Missing Layer}

In designing an eco-village, important building blocks or layers are to be considered. On the top layer is the physical layer that constitutes the biological system and the built environment. Gilman noted that beneath this physical layer is the human layer that constitutes the economic and governance of the village. These layers have also become the main challenges of an eco-village (Gilman, 1991).

\begin{tabular}{|c|c|}
\hline \multicolumn{2}{|c|}{ Whole system } \\
\hline Bio-system & Built-environment \\
\hline Economic & Governance \\
\hline \multicolumn{2}{|c|}{ Glue } \\
\hline
\end{tabular}

Figure 1. The Eco-village Layers

As most authors (Gilman, 1991; Mayerl, 2010) would put it, shared vision and ideals are necessary to glue the different layers.

While this seminal work has been the major anchor of past and contemporary developments, one of the major criticisms here is the missing connection of the different blocks, how the shared vision and ideals would glue all of them.

\section{The Drive to Eco-Village}

An eco-village is an "intentional village with green principles” (EarthTalk, 2008). This means that on the onset, there is the conscious and deliberate effort to define the living style in the community, essentially prioritizing a symbiotic human and nature relationship. This emphasizes a pre-defined mindset of perpetual communion of the community with the environment. And such mindset prescribes high-level of discipline and established practices to withstand environment changes such as political, economical, technological or socio-cultural variables.

So the decisional drive to settle in an eco-village is not as straightforward to buying a house based on factors such as income or proximity to workplace. As reiterated, it is a deliberate decision entailing a strong, focused mindset. It likewise recognizes the magnitude of responsibility to ensure balance of human and nature relationship. 


\section{Periphery Learning to Situated Learning}

Initially, when individuals decide to join a community, they stand at the periphery. This is where they learn. After gaining confidence and learning the different functions and activities in the community, individuals move gradually from the periphery to the center of the community to engage in full participation (Smith, 2003; 2009). In this situation, the learning and the collective learning performed and acquired by the individuals take place not though formal education but through social participation. Most of the incidents that the individuals encountered are activities and processes that made them engage in legitimate participation as members of the community. These incidents provide them opportunities to acquire knowledge and skills.

According to Lave, the acquisition of the knowledge and skills is not just based on experiential exposure to the situation but learning based on the context of the social participation and interactions (Smith, 2003; 2009).

Wenger further cited that from fundamental physiological needs to satisfying safety, social and other pleasure needs, individuals are continuously and constantly pursuing all kinds of “enterprises”. These enterprises permit various forms of learning as interactions with one another and with the world take place. And as learning takes place and different interactions also take stage, "collective learning” results from all of these and leads to collective practices as well (Wenger, 2006). The collective learning and the collective practices are offshoots of the ecosystem of the drive for enterprises.

So putting together these ideas—-from periphery learning to situated learning, individuals become full participants in the community. The legitimate participation leads to collective learning as well as collective practices. And such collective practices are the requisites to sustaining an effective eco-village mindset.

\section{Building A Community Of Eco-Village Practitioners}

According to the Communities of Practice (COP) guru Etienne Wenger, "Communities of Practice are groups of people who share a concern or a passion for something they do and learn how to do it better as they interact regularly” (Wenger, 2006).

Three elements that differentiate a COP from a group or an ordinary community are the domain, the community and the practice. Domain refers to the eco-village. Membership in the eco-village is intentional and compels commitment. The members who join or decide to settle in an eco-village possess progressive level of competence and understanding of the ecosystem, the importance of 
balance in the human and nature relationship. The community consists of the members engaging in various interactions and discussions, sharing of knowledge and information, performing activities, building relationships that allow them to know each other. And the practice means members of the community are eco-village practitioners. They do not only share learning and practices, they "create resources of experiences, tools, stories, even solutions to recurring problems” (Wenger, 2006). The passion to sustain the eco-village, to learn and to do better their craft and the willingness to interact and participate regularly, differentiates a community of eco-village of practitioners.

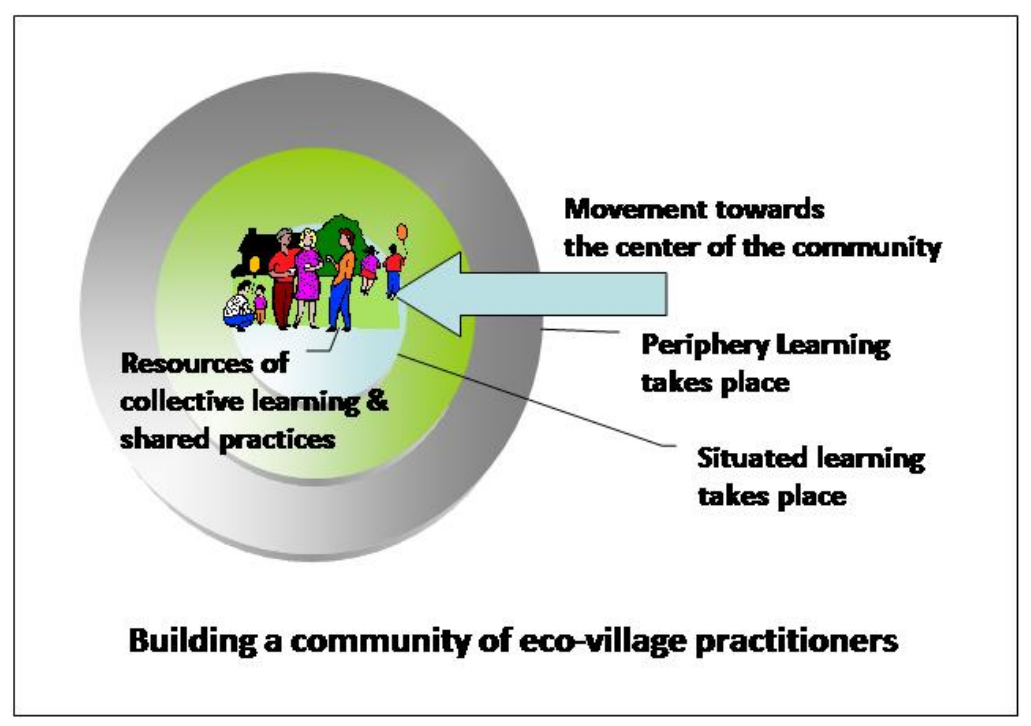

Figure 2. The Eco-village COP Approach

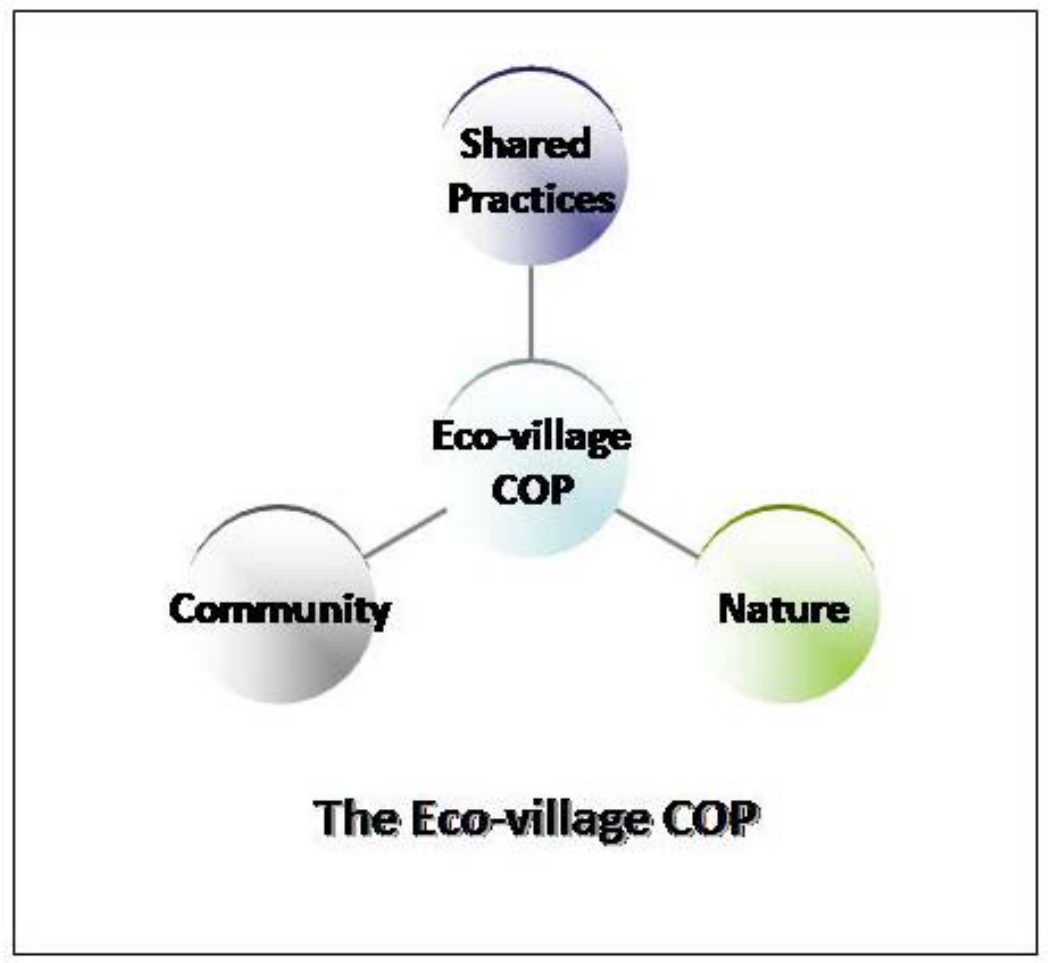

Figure 3. The Eco-village COP Model 


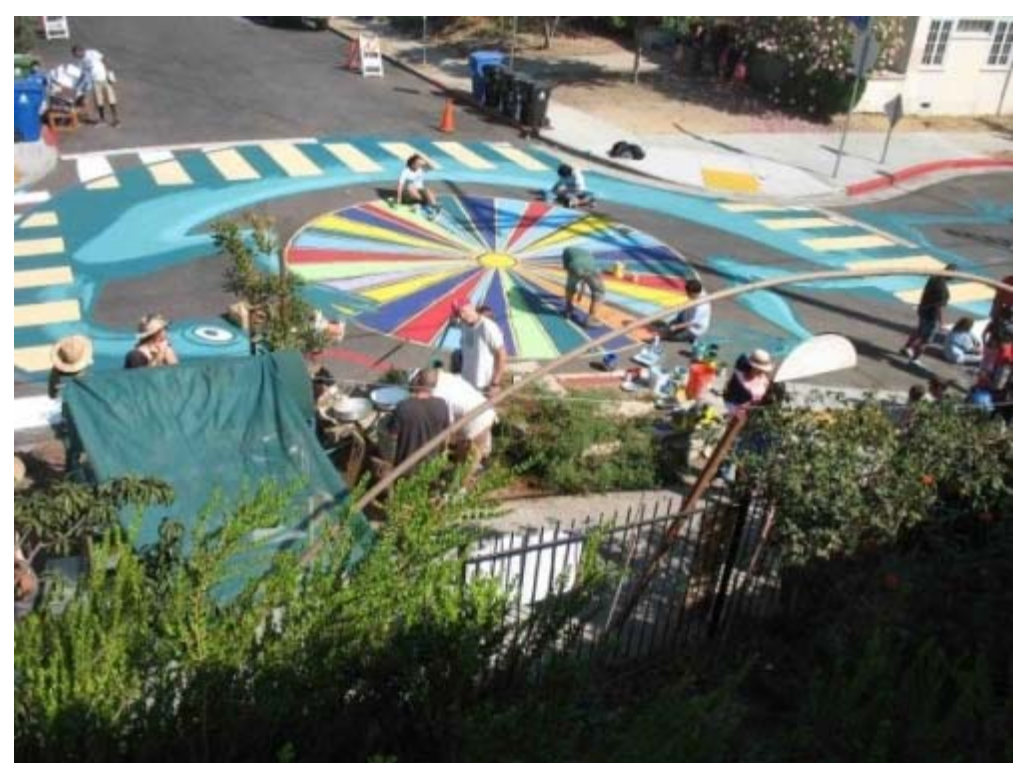

Photo 1. Bimini Place with Street Party and Road Painting, photo taken by Damien Newton Source: http://la.streetsblog.org/2009/09/15/eco-village-reclaims-bimini-pl-with-street-party-androad-painting/

Example 1. An example was the Bimini Place road painting and street party event held by the ecovillage members of Los Angeles in September 2009 (Newton, 2008). The activity was community initiated and mobilized with the goal of improving the road intersection through creation of a road paint mural and a bicycle lane. There were criticisms from other people because of the overriding decision of the community members. But this was a very good example of an activity encouraging situated learning and a sustained practice at the same time. The blogs created by the members to showcase this activity serve as resource site already.

Example 2. Another example is in Senegal (Svennson, 2000) where the COP consists of beliefs in ecology, community and spirituality. When a guest or a member of the community is ill, they offer fresh food or crops that they grow, herbal tea that they plant, attention and cheerful company as a recipe to good health.

Example 3. Munkesogaard Ecovillage in Roskilde, Denmark and Understenhodgen project in Stockholm, Sweden, both situated in the suburbs and employed co-housing ideas (Mayerl, 2010). Co-housing ideas refer to collaborative housing with shared facilities that encourage traditional village cooperation and sharing of interests. Parking, kindergarten, ecological building are some of the common facilities. Building layout employs community design and there is the cooperative finance managed by the members and the housing association.

Success in the given examples depended heavily on the confidence of the members that they are engaging and doing the right things. Determination of what the right thing to do takes time. The 
deliberate effort to participate, to learn and to practice what it is like to live in an eco-village is also a consensus decision, espoused and absorbed through time.

\section{What Important Aspects of The Eco-Village Cop Warrants The Use or Support of Technology?}

Collective learning and shared practices of a COP are knowledge and skills that are primarily tacit in form and need to be codified and made into explicit. Explicit knowledge is formal, organized, known and understood by all the members of the community. This way, explicit knowledge may be used, reused or even institutionalized. Transforming knowledge and skills into its codified form may or may not lend the need for technology.

In the case of an eco-village where it is considered an "intentional green principled community" and the members possess discipline, understanding and accountability of their human settlement, knowledge and skills come in different levels, in various occasions. So as the community matures and thrive to become a COP, the eco-village learns and develops shared practices and learning that are best echoed, taught and preserved through technology.

Use of technology-based social media such as videos, podcasts and blogs deployed in the web can be a practical, cost-effective solution to enhancing or preserving the practices. Social media would also pull the members effectively since the fundamental strategy when they acquired the knowledge and skills were through social participation. Present social media likewise encourages the ecovillage members to create the content based on their know-how and experiences. Development of permaculture for instance, come in different ways. This may be recorded through a phone video and get to be deployed in a free host site like Youtube. Discussions of the use of eco-friendly housing materials may be posted in blogs such as Wordpress, Blogger or Tumblr for everyone to read. Meetings and discussions may utilize podcasts for easy reference and playback. Twitter, a form of short messaging in the web, can also be a useful community communication tool to announce activities or alert the members of important concerns in the village. An alternate to the Twitter is the SMS, the short messaging system through the mobile phone.

\section{Conclusions}

While there are varied interest-based activities in the community, what will attract, bond or keep the members continue their practice of collective learning is the very reason they have decided to settle in an eco-village. Being in an eco-village has already differentiated the members. 
Using periphery learning and situated learning as models to attract the members more to the core of the community are meaningful and pragmatic. Both periphery and situated learning encourages social participation and there are many opportunities available in the eco-village. Once these members move from the periphery to the center, high level of participation is predicted. This participation, supplemented by dynamic and fun activities that enhances acquisition of more knowledge and better skills accentuate the members' becoming practitioners in the community. And this is the key to a sustainable eco-village. Once the members have progressed to the level of mature practitioners, there is no way that the eco-village will not be able to address the ecosystem of relationships and reach its best potential.

\section{References}

EarthTalk. (2008). Revolutionary “eco-villages” sprout up across the world, The Environmental Magazine, www.thedailygreen.com/environmental-news/latest/eco-villages-461108 .

Gilman, R. (1991). The Eco-village challenge, Living Together (IC\#29), Summer 1991, p. 10, www.context.org/ICLIB/IC29/Gilman1.htm.

Mayerl, R. (2010). 'Examples of Co-housing Projects', Alternative housing and living, www.habiter-autrement.org/04_co-housing/coh_ca.htm.

Mayerl, R. (2010). The Ecovillage Model Introduction, Alternative housing and living, www.habiter-autrement.org/05.eco-village/01_eco.htm .

Newton, D. (2008). “Ecovillage reclaims Bimini place with street party and road painting”, www.LAStBlog.org.

Smith, M. K. (2003, 2009). 'Communities of practice', the encyclopedia of informal education, www.infed.org/biblio/communities_of_practice.htm.

Svennson, K. (2000). 'Ecovillages: Listening to the voice of man and nature', Ecovillage Millennium, Jan. 2000, p. 3-4.

Wenger, W. (2006). 'Communities of practice a brief introduction', www.ewenger.com/theory/. 